\title{
Factors that contribute to a NANDA nursing diagnosis of risk for frail elderly syndrome
}

\author{
Fatores que contribuem para o diagnóstico de enfermagem risco para a síndrome \\ do idoso frágil
}

Factores que contribuyen para el diagnóstico de enfermería riesgo para el síndrome del anciano frágil

\author{
Maria da Graça Oliveira Crossetti ${ }^{\mathrm{a}}$ \\ Michele Antunes ${ }^{b}$ \\ Beatriz Ferreira Waldmanc \\ Margarita Ana Rubin Unicovskyc \\ Lucas Henrique de Rosso ${ }^{a}$ \\ Letice Dalla Lana ${ }^{\mathrm{a}, \mathrm{d}}$
}

How to cite this article: Crossetti MGO, Antunes M, Waldman BF, Unicovsky MAR, Rosso LH, Lana LD. Factors that contribute to a NANDA nursing diagnosis of risk for frail elderly syndrome. Rev Gaúcha Enferm. 2018;39:e20170233. doi: https://doi.org/10.1590/19831447.2018.2017-0233 a Universidade Federal do Rio Grande do Sul (UFRGS), Escola de Enfermagem, Programa de Pós- graduação em Enfermagem. Porto Alegre, Rio Grande do Sul, Brasil.

a Universidade Federal do Rio Grande do Sul (UFRGS), Programa de Pós-graduação em Informática na Educação. Porto Alegre, Rio Grande do Sul, Brasil.

b Universidade Federal do Rio Grande do Sul (UFRGS), Escola de Enfermagem, Departamento de Enfermagem Médico-Cirúrgica. Porto Alegre, Rio Grande do Sul, Brasil.

Universidade Federal do Pampa (UNIPAMPA). Curso de Graduação em Enfermagem, Campus Uruguaiana. Uruguaiana, Rio Grande do Sul, Brasil.
RESUMO

Objetivo: Identificar os fatores de risco que contribuem com o diagnóstico de enfermagem Risco de síndrome do idoso frágil da NANDA-I. Método: Estudo transversal com 395 idosos entre novembro de 2010 a janeiro de 2013, num hospital escola do Sul do Brasil. Foram coletados dados sociodemográficos e identificados os níveis de fragilidade pela Escala de Edmonton.

Resultados: Foram identificados $177(44,81 \%)$ idosos com fragilidade. Houve associação significativa entre fragilidade e sexo feminino ( $p=0,031)$, cor não branca $(p=0,008)$, sem companheiro $(p=0,014)$, nenhuma escolaridade $(p=0,001)$, renda mensal inferior a um salário mínimo $(p=0,034)$, morbidades preexistentes para doenças do aparelho respiratório $(p=0,003)$ e doenças infecciosas e parasitárias $(p=0,040)$. As doenças do aparelho geniturinário $(p=0,035)$, respiratório $(p=0,001)$ e do sangue $(p=0,035)$ foram os principais motivos de internação.

Conclusão: Os resultados contribuem para o desenvolvimento e implementação do diagnóstico de enfermagem em estudo no ambiente hospitalar.

Palavras-chave: Idoso fragilizado. Diagnóstico de enfermagem. Idoso. Enfermagem.

\section{ABSTRACT}

Objective: Identify the risk factors that contribute to a NANDA-I nursing diagnosis of risk for frail elderly system.

Method: Cross-sectional study with 395 elderly subjects, conducted from November 2010 to January 2013, in a university hospital in South of Brazil. Sociodemographic data were collected and levels of frailty were identified according to the Edmonton Frail Scale. Results: A total of 177 (44.81\%) participants were classified as frail. There was a significant association between frailty and being female ( $p=0.031)$, nonwhite $(p=0.008)$, having no romantic partner $(p=0.014)$, no schooling $(p=0.001)$, a monthly income lower than the minimum wage $(p=0.034)$, and preexisting morbidities for respiratory diseases $(p=0.003)$ as well as infectious and parasitic diseases $(p=0.040)$. Diseases of the tracts genitourinary $(p=0.035)$, respiratory $(p=0.001)$ and blood $(p=0.035)$ were the primary reasons for hospitalization.

Conclusion: The results contribute to the development and implementation of the nursing diagnosis in the hospital setting Keywords: Frail elderly. Nursing diagnosis. Aged. Nursing.

\section{RESUMEN}

Objetivo: Identificar los factores de riesgo que contribuyen con el diagnóstico de enfermería: Riesgo de Síndrome del Anciano Frágil de NANDA-I.

Método: Estudio transversal con 395 ancianos entre noviembre de 2010 hasta enero de 2013, en un hospital universitario en Sur de Brasil. Fue recolectado datos sociodemográficos e identificado los niveles de fragilidad por la Escala de Edmonton.

Resultados: Fueron identificados $177(44,81 \%)$ ancianos con fragilidad. Hubo asociación significativa entre fragilidad y sexo femenino ( $p=0,031)$, color no blanca $(p=0,008)$, sin compañero $(p=0,014)$, ninguna escolaridad $(p=0,001)$, renta mensual inferior a un salario mínimo $(p=0,034)$, morbilidad preexistente para enfermedades del aparato respiratorio $(p=0,003)$ y enfermedades infecciosas y parasitarias $(p=0,040)$. Las enfermedades del aparato genitourinario $(p=0,035)$, del respiratorio $(p=0,001)$ y del sangre ( $p=0,035$ ) fueron significativas como razón de hospitalización

Conclusión: Los resultados contribuyen para el desarrollo e implementación del diagnóstico de enfermería en estudio en el ambiente hospitalario.

Palabras-clave: Anciano frágil. Diagnóstico de enfermería. Anciano. Enfermería. 


\section{口INTRODUCTION}

When evaluated based on the unidimensional phenotype proposed by Fried et al. (1), the prevalence of frailty among the elderly is $6.9 \%$, evaluated according to the following criteria: unintentional weight loss in the previous year, decline in grip strength, low level of physical activity, self-reported fatigue and slower gait.

As a multidimensional syndrome, the prevalence of frailty rises to $74.1 \%$ in nursing homes and $50.6 \%$, corroborating interaction between frailty and biological, psychological, cognitive, social and environmental factors experienced by the elderly over time ${ }^{(2-3)}$. Some of these factors are characterized as non-modifiable because of the progressive and irreversible aging process; however, others are susceptible to health intervention, potentially leading to the development or modification of frailty outcomes such as disability, hospitalization and death ${ }^{(4)}$.

The cause and effect between frailty and hospitalization has yet to be determined ${ }^{(5)}$, but frailty prevalence and scores show high death rates among fragile elderly in hospital settings $s^{(6)}$. The prevalence of frailty among 84 hospitalized elderly patients was $95.2 \%$, with frailty scores indicating that 4 (4.8\%) subjects were considered apparently vulnerable, 28 (33.3\%) mildly frail, 16 (19\%) moderate and $36(42.9 \%)$ severe $^{(7)}$.

In light of this scenario, frailty in hospitalized elderly individuals requires action aimed at preventing and treating this syndrome. To that end, nurses should periodically conduct a systematic and dynamic assessment of frail elderly patients and devise an individual care plan. This is achieved through the nursing process, which uses clinical judgment and decision making to establish nursing diagnoses (NDs), interventions and results. The NDs of the North American Nursing Diagnosis Association (NANDA-I) list include risk for frail elderly syndrome, which contributes to devising care practices aimed at preventing this clinical condition.

As such, early identification of the ND allows nurses to intervene in the care of the elderly patient, since the outcome of frailty syndrome (FS) is worsening health problems and ultimately death. Thus, there is a need to investigate risk factors and development as well as care possibilities and implications as a preventive and rehabilitative strategy for frail or potentially frail elderly individuals.

In light of the above, the following research question emerged: what are the risk factors that contribute to a NANDA-I nursing diagnosis of risk for frail elderly system? The present study aimed to identify the risk factors that contribute to a NANDA-I nursing diagnosis of risk for frail elderly system.

\section{METHOD}

This is a cross-sectional analytical study conducted in a university hospital in southern Brazil in five inpatient care units, where patients included elderly individuals with non communicable diseases; and seven surgical units that provide pre- or postoperative care to adults and elderly patients in different specialties.

Subjects were elderly patients admitted to the respective care units who met the following inclusion criteria: age equal to or greater than 60 years, able to satisfactorily answer questions during application of the Edmonton Frail Scale ${ }^{(8)}(\mathrm{EFS})$, and capable of waking with or without assistance (cane and/or a person). The exclusion criterion was elderly individuals in the postoperative phase after hip replacement surgery.

Sampling was by convenience and included 395 elderly patients analyzed from November 2010 to January 2013, using two sequential instruments. The first aimed to obtain sociodemographic data such as age in completed years, marital status, sex, religion, schooling level in years, family income based on minimum wage, skin color, preexisting morbidities and reason for hospitalization. The second instrument was the EFS, applied to identify frailty ${ }^{(8)}$.

The EFS was created by the University of Alberta in Edmonton, Canada and was transcribed and cross-culturally validated for Brazil in 2008 ${ }^{(8)}$. It covers nine domains: cognition (clock drawing test - CDT), general health status, functional independence, social support, medication use, nutrition, mood, continence, and functional performance (timed up and go test), assessed by 11 items. The items were scored over three columns A to C, where A denoted zero points, B one and $C$ two, for a maximum score of 17 , representing the highest level of frailty. Thus, the frailty assessment scores are: 0-4 not frail, 5-6 apparently vulnerable, 7-8 mild frailty, 9-10 moderate frailty, and 11 or more severe frailty ${ }^{(8)}$.

The data were processed by compiling a database in Predictive Analytics Software (PASW), version 18. The data were analyzed using descriptive statistics, followed by the chi-squared test $\left(X^{2}\right)$ to assess the association between the sociodemographic variables, preexisting morbidities, reasons for hospitalization and frailty profiles of the elderly subjects. A 95\% confidence interval was adopted $(a<0.05)$.

The project entitled "Frailty in the elderly: evidence for the development of the nursing diagnoses "Risk for frail elderly syndrome" and "Frail elderly syndrome", which gave rise to this manuscript, was approved by the Research Committee of the Nursing School of the Universidade Federal do Rio Grande do Sul (UFRGS) under protocol no. 005/2010 
and the HCPA Research Ethics Committee (no. 100172), in line with the ethical requirements of Resolution 466/2012 of the Brazilian National Health Council. Data collection began once authorization had been granted. All the participants gave written informed consent, with researchers retaining one copy and another given to the subjects.

\section{RESULTS}

Of the 395 participants studied, 245 (62\%) were hospitalized in surgical units and 150 (38\%) in inpatient care units. Age ranged from 60 to 94 years (mean age 69.73; $\mathrm{SD}= \pm 7.23)$ and 248 (62.8\%) subjects were men, 329 (83.3\%) white, 247 (62.5\%) had a romantic partner, 375 (95\%) held religious beliefs, 372 (94.2\%) were educated, 391 (99\%) earned a monthly income greater than one minimum wage, and 331 (83.8\%) exhibited a preexisting morbidity.

With respect to frailty levels, 177 subjects (44.8\%) were identified as frail, of which 82 (20.8\%) displayed mild frailty, 53 (13.4\%) moderate and 42 (10.6\%) severe. Among the 218 participants without the clinical conditions for frailty,
114 (28.9\%) were classified as not frail and 104 (26.3\%) apparently frail (Table 1).

Table 1 - Prevalence of frailty among hospitalized elderly. Porto Alegre, RS, Brazil, 2017

\begin{tabular}{lcc}
\hline Frailty Score & $\mathbf{n}$ & $\%$ \\
\hline (0-4) - Not frail & 114 & 28.9 \\
(5-6) - Apparently vulnerable & 104 & 26.3 \\
(7-8) - Mild frailty & 82 & 20.8 \\
(9-10) - Moderate frailty & 53 & 13.4 \\
(11 or more) - Severe frailty & 42 & 10.6 \\
\hline Total & 395 & 100 \\
\hline
\end{tabular}

Source: Research data, 2017

With respect to the association between the variables sociodemographic characteristics and frailty level, significant results were obtained for female sex $(p=0.031)$, nonwhite $(p=0.008)$, no romantic partner $(p=0.014)$, no schooling ( $p=0.001)$, and monthly income less than one minimum wage ( $p=0.034$ ) (Table 2 ).

Table 2 - Association between sociodemographic variables and frailty levels. Porto Alegre, RS, Brazil, 2017

\begin{tabular}{|c|c|c|c|c|c|c|c|}
\hline \multirow{2}{*}{$\begin{array}{c}\text { Socio } \\
\text { demographic } \\
\text { Characteristics }\end{array}$} & \multicolumn{6}{|c|}{ Frailty Levels } & \multirow[b]{2}{*}{$p$-value } \\
\hline & $\begin{array}{c}\text { Not fragile } \\
(\%)\end{array}$ & $\begin{array}{c}\text { Apparently } \\
\text { vulnerable } \\
\text { (\%) }\end{array}$ & $\begin{array}{c}\text { Mild frailty } \\
(\%)\end{array}$ & $\begin{array}{c}\text { Moderate } \\
\text { frailty } \\
(\%)\end{array}$ & $\begin{array}{c}\text { Severe } \\
\text { frailty } \\
(\%)\end{array}$ & $\begin{array}{c}\text { Total } \\
(\%)\end{array}$ & \\
\hline \multicolumn{8}{|l|}{ Sex } \\
\hline Female & $35(23.8)$ & $32(21.8)$ & $34(23.1)$ & $28(19.1)$ & $18(12.2)$ & 147 (37.2) & $<.031$ \\
\hline Male & 79 (31.8) & $72(29.0)$ & $48(19.4)$ & $25(10.1)$ & $24(9.7)$ & $248(62.8)$ & \\
\hline Total & $114(28.9)$ & $104(26.3)$ & $82(20.8)$ & $53(13.4)$ & $42(10.6)$ & $\begin{array}{c}395 \\
(100,0)\end{array}$ & \\
\hline \multicolumn{8}{|l|}{ Color } \\
\hline White & $104(31.6)$ & $84(25.5)$ & $69(21.0)$ & $44(13.4)$ & $28(8.5)$ & $329(83.3)$ & \\
\hline Nonwhite & $10(15.2)$ & $20(30.3)$ & $13(19.7)$ & $9(13.6)$ & $14(21.2)$ & $66(16.7)$ & $<.008$ \\
\hline Total & $114(28.9)$ & $104(26.3)$ & $82(20.8)$ & $53(13.4)$ & $42(10.6)$ & $\begin{array}{c}395 \\
(100.0)\end{array}$ & \\
\hline \multicolumn{8}{|l|}{ Marital status } \\
\hline Romantic partner & 78 (31.6) & $70(28.3)$ & $54(21.9)$ & $26(10.5)$ & $19(7.7)$ & $247(62.5)$ & \\
\hline $\begin{array}{c}\text { No romantic } \\
\text { partner }\end{array}$ & $36(24.3)$ & $34(23.0)$ & $28(18.9)$ & $27(18.2)$ & $23(15.6)$ & $148(37.5)$ & $<.014$ \\
\hline Total & $114(28,9)$ & $104(26.3)$ & $82(20.8)$ & $53(13.4)$ & $42(10.6)$ & $\begin{array}{c}395 \\
(100.0)\end{array}$ & \\
\hline \multicolumn{8}{|l|}{ Religion } \\
\hline $\begin{array}{l}\text { Hold religious } \\
\text { beliefs }\end{array}$ & $109(29.1)$ & $98(26.1)$ & $77(20.6)$ & $53(14.1)$ & $38(10.1)$ & $375(95.0)$ & \\
\hline
\end{tabular}


Crossetti MG0, Antunes M, Waldman BF, Unicovsky MAR, Rosso LH, Lana LD

\begin{tabular}{|c|c|c|c|c|c|c|c|}
\hline Not religious & $5(25.0)$ & $6(30.0)$ & $5(25.0)$ & $0(0.0)$ & $4(20.0)$ & $20(5.0)$ & \\
\hline Total & 114 (28.9) & $104(26.3)$ & $82(20.8)$ & $53(13.4)$ & $42(10.6)$ & $\begin{array}{c}395 \\
(100.0)\end{array}$ & \\
\hline \multicolumn{8}{|l|}{ Schooling } \\
\hline Uneducated & $1(4.4)$ & $9(39.1)$ & $4(17.4)$ & $2(8.7)$ & 7 (30.4) & $23(5.8)$ & $<.001$ \\
\hline Educated & & & & & & & \\
\hline $\begin{array}{c}\text { (1 to } 13 \text { years } \\
\text { of schooling or } \\
\text { more) }\end{array}$ & $\begin{array}{c}113 \\
(30.4)\end{array}$ & $95(25.5)$ & $78(21.0)$ & $51(13.7)$ & $35(9.4)$ & $\begin{array}{c}372 \\
(94.2)\end{array}$ & \\
\hline Total & $114(28.9)$ & $104(26.3)$ & $82(20.8)$ & $53(13.4)$ & $42(10.6)$ & $\begin{array}{c}395 \\
(100.0)\end{array}$ & \\
\hline \multicolumn{8}{|l|}{$\begin{array}{l}\text { Monthly salary in } \\
\text { minimum wages }\end{array}$} \\
\hline $\begin{array}{l}\text { Less than one } \\
\text { minimum wage }\end{array}$ & $1(25.0)$ & $2(50.0)$ & $1(25.0)$ & $0(0.0)$ & $0(0.0)$ & $4(1.0)$ & $<.034$ \\
\hline $\begin{array}{l}\text { More than one } \\
\text { minimum wage } \\
\text { (1 to } 5 \text { minimum } \\
\text { wages or more) }\end{array}$ & $113(28.9)$ & $102(26.1)$ & $81(20.7)$ & $53(13.6)$ & $42(10.7)$ & 391 (99.0) & \\
\hline Total & $114(28.9)$ & $104(26.3)$ & $82(20.8)$ & $53(13.4)$ & $42(10.6)$ & $\begin{array}{c}395 \\
(100.0)\end{array}$ & \\
\hline
\end{tabular}

Presence of

preexisting

morbidity

$\begin{array}{ccccccc}\text { Present } & 87(26.3) & 84(25.4) & 71(21.4) & 48(14.5) & 41(12.4) & 331(83.8) \\ \text { Absent } & 27(42.2) & 20(31.2) & 11(17.2) & 5(7.8) & 1(1.6) & 64(16.2) \\ \text { Total } & 114(28.9) & 104(26.3) & 82(20.8) & 53(13.4) & 42(10.6) & 395 \\ \end{array}$

Source: Research data, 2017.

${ }^{*} X^{2}$ test. $5 \%$ significance level ( $p$-value $<0.05$ ).

Given the high number of preexisting morbidities and reasons for hospitalization among the elderly studied, diseases were classified according to the International Classification of Diseases (ICD-10). Table 3 depicts the associ- ation between frailty levels and preexisting morbidities in the hospitalized elderly subjects, obtaining statistical significance for respiratory $(p=0.003)$, infectious and parasitic diseases $(p=0.040)$.

Table 3 - Association between preexisting morbidities and frailty levels. Porto Alegre, RS, Brazil, 2017

\begin{tabular}{|c|c|c|c|c|c|c|c|}
\hline \multirow[b]{2}{*}{$\begin{array}{l}\text { Preexisting mor- } \\
\text { bidity }\end{array}$} & \multicolumn{7}{|c|}{ Frailty Levels } \\
\hline & $\begin{array}{c}\text { Not fragile } \\
(\%)\end{array}$ & $\begin{array}{c}\text { Apparently } \\
\text { vulnerable } \\
(\%)\end{array}$ & $\begin{array}{l}\text { Mild frailty } \\
(\%)\end{array}$ & $\begin{array}{c}\text { Moderate } \\
\text { frailty } \\
(\%)\end{array}$ & $\begin{array}{c}\text { Severe } \\
\text { frailty } \\
(\%)\end{array}$ & $\begin{array}{c}\text { Total } \\
(\%)\end{array}$ & $p$-value* \\
\hline $\begin{array}{c}\text { Circulatory system } \\
\text { diseases }\end{array}$ & $63(31.0)$ & 48 (23.6) & $42(20.7)$ & $30(14.8)$ & $20(9.9)$ & $203(51.4)$ & \\
\hline $\begin{array}{c}\text { Endocrine and } \\
\text { nutritional diseases }\end{array}$ & 35 (18.8) & $43(23.1)$ & 49 (26.4) & $29(15.6)$ & $30(16.1)$ & $186(47.1)$ & \\
\hline Malignancies & $13(30.2)$ & 8 (18.6) & $11(25.6)$ & 8 (18.6) & $3(7.0)$ & $43(10.9)$ & \\
\hline
\end{tabular}




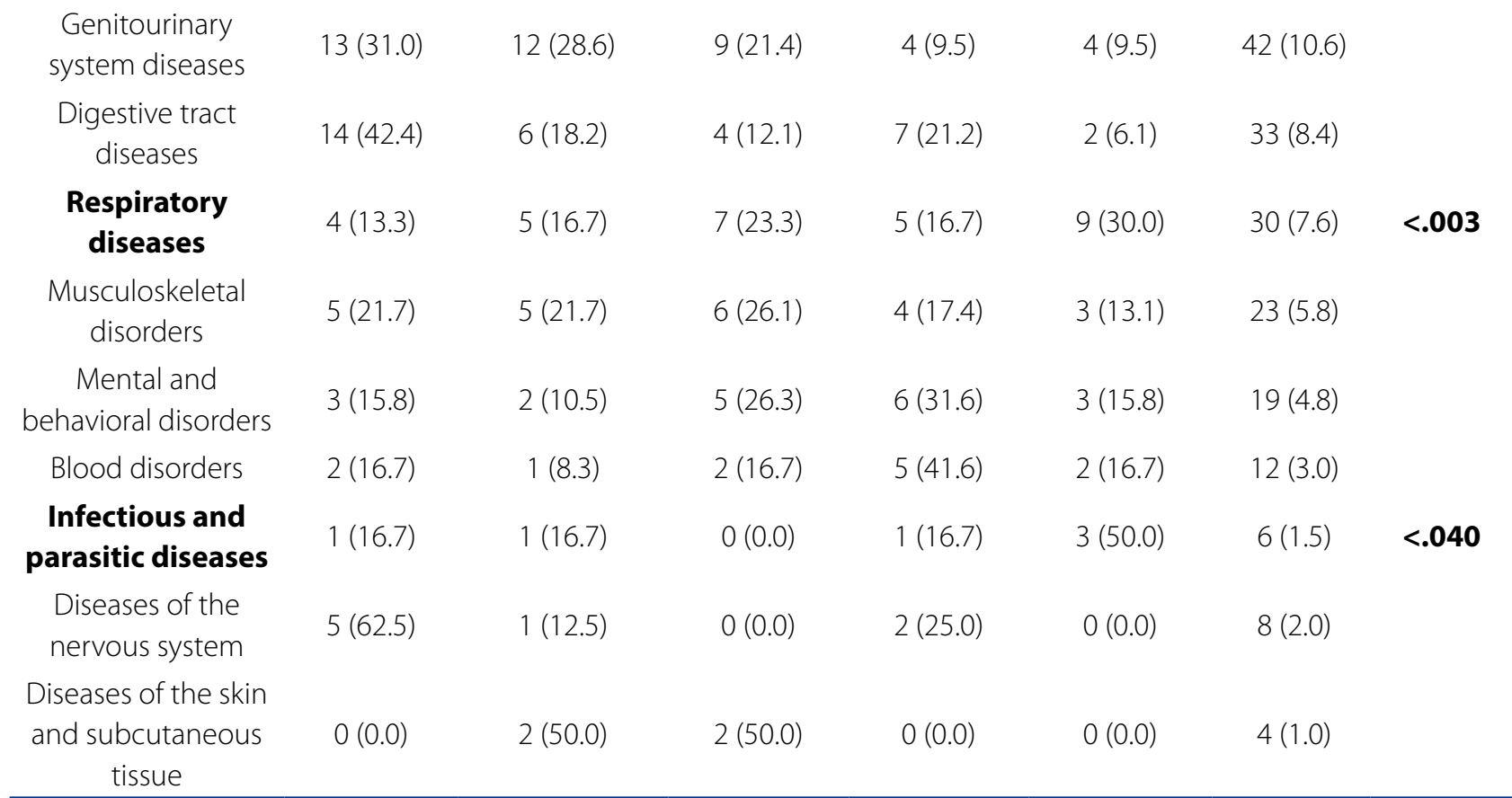

Source: Research data, 2017

${ }^{*} X^{2}$ test. $5 \%$ significance level ( $p$-value $<0.05$ ).

The morbidities that prompted hospitalization were also categorized according to ICD-10 and associated with frailty levels, with statistically significant results observed for frailty levels and genitourinary system ( $p=0.035)$, respiratory $(p=0.001)$ and blood disorders $(p=0.035)$, as shown in Table 4.

Table 4 - Association between the morbidities that prompted hospitalization and frailty levels. Porto Alegre, RS, Brazil, 2017

\begin{tabular}{|c|c|c|c|c|c|c|c|}
\hline \multirow[b]{2}{*}{$\begin{array}{l}\text { Morbidity } \\
\text { prompting hos- } \\
\text { pitalization }\end{array}$} & \multicolumn{7}{|c|}{ Frailty Levels } \\
\hline & $\begin{array}{l}\text { Not fragile } \\
(\%)\end{array}$ & $\begin{array}{c}\text { Apparently } \\
\text { vulnerable } \\
(\%)\end{array}$ & $\begin{array}{l}\text { Mild frailty } \\
\text { (\%) }\end{array}$ & $\begin{array}{c}\text { Moderate } \\
\text { frailty } \\
(\%)\end{array}$ & $\begin{array}{l}\text { Severe } \\
\text { frailty } \\
(\%)\end{array}$ & $\begin{array}{l}\text { Total } \\
(\%)\end{array}$ & p-value* \\
\hline $\begin{array}{c}\text { Circulatory system } \\
\text { diseases }\end{array}$ & $15(21.8)$ & $21(30.4)$ & $15(21.8)$ & $9(13.0)$ & $9(13.0)$ & $69(17.5)$ & \\
\hline $\begin{array}{c}\text { Endocrine and } \\
\text { nutritional diseases }\end{array}$ & $3(18.7)$ & $4(25.0)$ & $5(31.3)$ & $0(0.0)$ & $4(25.0)$ & $16(41)$ & \\
\hline Malignancies & $33(25.4)$ & $42(32.3)$ & $29(22.3)$ & $16(12.3)$ & $10(7.7)$ & $130(32.9)$ & \\
\hline $\begin{array}{l}\text { Genitourinary } \\
\text { system diseases }\end{array}$ & $26(43.4)$ & $14(23.3)$ & $8(13.3)$ & $10(16.7)$ & $2(3.3)$ & $60(15.2)$ & $<.035$ \\
\hline $\begin{array}{l}\text { Digestive tract } \\
\text { diseases }\end{array}$ & $18(40.9)$ & $9(20.5)$ & $8(18.2)$ & $6(13.6)$ & $3(6.8)$ & $44(11.1)$ & \\
\hline $\begin{array}{l}\text { Respiratory } \\
\text { diseases }\end{array}$ & $8(22.2)$ & $3(8.3)$ & $5(13.9)$ & $7(19.5)$ & $13(36.1)$ & $36(9.1)$ & $<.001$ \\
\hline $\begin{array}{l}\text { Musculoskeletal } \\
\text { disorders }\end{array}$ & $7(43.7)$ & $5(31.2)$ & $1(6.3)$ & $3(18.8)$ & $0(0.0)$ & $16(4.1)$ & \\
\hline
\end{tabular}




\begin{tabular}{|c|c|c|c|c|c|c|c|}
\hline $\begin{array}{c}\text { Mental and } \\
\text { behavioral } \\
\text { disorders }\end{array}$ & $0(0.0)$ & $2(50.0)$ & $1(25.0)$ & $1(25.0)$ & $0(0.0)$ & $4(1.0)$ & \\
\hline Blood disorders & $0(0.0)$ & $2(20.0)$ & $5(50.0)$ & $1(10.0)$ & $2(20.0)$ & $10(2.5)$ & $<.035$ \\
\hline $\begin{array}{c}\text { Certain infectious } \\
\text { and parasitic } \\
\text { diseases }\end{array}$ & $0(0.0)$ & $5(62.5)$ & $1(12.5)$ & $1(12.5)$ & $1(12.5)$ & $8(2.0)$ & \\
\hline $\begin{array}{l}\text { Diseases of the } \\
\text { nervous system }\end{array}$ & $3(50.0)$ & $0(0.0)$ & $2(33.3)$ & $1(16.7)$ & $0(0.0)$ & $6(1.5)$ & \\
\hline $\begin{array}{c}\text { Diseases of the skin } \\
\text { and subcutaneous } \\
\text { tissue }\end{array}$ & $0(0.0)$ & $0(0.0)$ & $2(66.7)$ & $1(33.3)$ & $0(0.0)$ & $3(0.7)$ & \\
\hline
\end{tabular}

Source: Research data, 2017.

${ }^{*} X^{2}$ test. $5 \%$ significance level ( $p$-value $<0.05$ ).

\section{DDISCUSSION}

Research evaluating frailty according to the criteria of Fried et al. (1) found a prevalence of $6,9 \%$ to $40 \%$ in elderly individuals in the community and hospital setting, respectively ${ }^{(1,9)}$. When compared to frailty levels identified by the EFS, prevalence was greater than $36.7 \%$ in elderly subjects undergoing outpatient treatment and $41.3 \%$ in non-institutionalized elderly ${ }^{(10-11)}$. This increase in prevalence is consistent with the influence of the psychological, emotional, social and environmental domains in the EFS, which goes beyond the physiological aspects assessed by Fried et al.(1). In this respect, the frailty prevalence percentages recorded in the present study are in line with the multidimensional concept that increases the likelihood of hospitalization in the elderly.

The multidimensional concept of frailty is identified in the ND Risk for frail elderly syndrome, characterized as a decline in one or more health domains, indicating increased susceptibility to adverse effects ${ }^{(12)}$. This ND contains risk factors defined as influences that heighten the vulnerability of individuals to certain unhealthy event ${ }^{(12)}$.

Despite predominating among the hospitalized subjects, white skin color did not show significant results for risk of frailty, whereas nonwhites were at significant risk for this clinical condition. Ethnicity other than Caucasian is also identified as a risk factor for the ND under study. However, this finding does not prove that black skin color is a primary demographic factor that determines frailty ${ }^{(13)}$, since there are additional ethnicities present in Brazil.

With respect to sex, despite of the high number of elderly men hospitalized, frailty was significant among the women. This has been observed in national and inter- national studies carried out in the community, nursing homes, hospitals and home care setting $s^{(1,3,7)}$.

The association between frailty, being female and nonwhite demonstrates that these non-modifiable variables in the biological domain can increase the vulnerability of elderly individuals. As such, the presence of these factors does not characterize the elderly subject as frail because the syndrome is multidimensional and involves biological, physical, functional, cognitive, social, economic and environmental factors.

The economic factor of monthly income less than one minimum wage, characterized as a modifiable condition, can be deemed a financial disadvantage according to NANDA- ${ }^{(12)}$. A Brazilian study found that monthly identified was the main factor associated with frailty, indicating that the worse the financial situation, the greater the risk of an elderly person being frail ${ }^{(10)}$. The findings of the present study corroborate the ND analyzed, since low-income elderly individuals who are hospitalized are at greater risk of frailty due to financial difficulties in maintaining their health status, resulting in reduced functional capacity, increased health-related expenditure owing to aging and less access to healthcare services ${ }^{(14)}$.

With respect to education, an association was observed between frailty and low schooling levels ${ }^{(1,11)}$, which vary from one to years of study ${ }^{(7)}$. However, the present study found that being uneducated, that is, zero years of schooling, is a significant risk factor for frailty and also contributed to the clinical outcome of hospitalization.

Another modifiable risk factor for frailty is not having a romantic partner, which may be related to the deterioration of one or more social, psychological or environmental domains under the ND Risk for frail elderly syndrome ${ }^{(12) .}$ Although this risk factor is not cited in the ND, it can occa- 
sionally be associated with social isolation, despair, living alone, sadness and depression. Thus, the result of this study demonstrates that it should be included in the ND, largely because most of our sample were in a relationship.

Sociodemographic conditions did not directly affect the pathophysiological changes caused by frailty; however, exposure to these conditions could negatively affect healthy aging in the elderly. Thus, fragility, even being highlighted among the elderly, is not necessarily associated with aging ${ }^{(15)}$.

Aging involves a decline in the body's systems, including immunity, which, combined with frailty, promote a homeostatic and metabolic imbalance ${ }^{(1)}$ that may explain the prevalence of infectious and parasitic diseases among the frail elderly studied here. Another possible explanation is sociodemographic aspects such as low schooling levels and low income, which make the elderly more susceptible to these diseases.

Respiratory diseases were a significant reason for hospitalization among participants. This result is believed to be related to physiological changes in the respiratory system combined with aging-related anatomical changes ${ }^{(16)}$, as well with the life-time exposure to environmental pollution, intensifying the decline of the physiological domain of frailty and, consequently, the remaining domains of the syndrome. The impact of these diseases on frail elderly individuals highlights the importance of prevention and early identification among those in the community and rehabilitation in hospital settings.

Respiratory diseases are not cited in the ND Risk for frail elderly syndrome, but may be correlated with the chronic disease risk factor that affects these individuals ${ }^{(12)}$. Additionally, chronic respiratory diseases may be related to intolerance of activity, suppressed inflammatory response, age greater than 70 years and sedentary lifestyle, identified as risk factors on the NANDA-ן ${ }^{(12)}$.

It is believed that a clinically stable chronic disease is not sufficient cause for hospital treatment, meaning non-chronic or acute respiratory diseases carry a greater potential risk of hospitalization. As such, respiratory disorders should be viewed as both chronic and potentially unstable diseases that could lead to hospitalization or worsen the clinical picture of frailty.

Genitourinary system diseases were also identified as morbidities that cause hospitalization of fragility. This association of frailty with respiratory diseases and genitourinary infection was also significant in a sample composed by 203 elderly of that community ${ }^{(4)}$. This finding can be justified by the high prevalence of these disorders among elderly participants in this study, who were more vulnerable to urinary tract infections. It was also associated with urinary inconti- nence and the leakage of small amounts of urine several times a day ${ }^{(17)}$ due to physiological related to healthy aging, which weaken the urethral and pelvic muscles in women and enlarge the prostate among men.

The identification of a significant association between blood disorders and frailty may be related to polypharmacy, which is also a risk factor for frailty because it interferes in the ingestion, absorption, use and excretion of the nutrients in food ${ }^{(18)}$. This nutritional imbalance can lead to overweight and malnourishment, resulting in low total cholesterol, albumin and high-density lipoprotein (HDL) levels ${ }^{(19)}$, which are associated with coagulation disorders ${ }^{(20)}$, chronic diseases such as diabetes mellitus and depression, defined as risk factors for the ND in question ${ }^{(12)}$. The suggested inclusion of blood diseases as a risk factor in the ND could lead to more accurate diagnosis, even though these disorders may be related to other risk factors already included.

In light of the above, early identification of risk factors for frailty among hospitalized elderly is important to help nurses develop and implement the ND Risk for frail elderly syndrome for application in healthcare interventions aimed at preventing and reducing the outcomes of this syndrome.

\section{- CONCLUSIONS}

The findings of this study demonstrate that frailty can be predicted, since modifiable risk factors and a prevalence of apparently vulnerable elderly were identified. The number of subjects with mild and moderate frailty indicates that early diagnosis by nurses would allow the condition to be prevented and treated.

With respect to the ND Risk for frail elderly syndrome, the risk factors female gender and ethnicity other than Caucasian correspond to the statistically significant variables female sex and nonwhite. The factors no schooling and monthly income less than one minimum wage are partially covered in the ND, which does not specify educational levels and financial disadvantage in frail elderly.

Other significant risk factors that contribute to the ND and are not covered in the diagnosis of risk for frail elderly syndrome: no romantic partner, preexisting respiratory, parasitic and infectious diseases, and genitourinary, respiratory and blood disorders as motives for hospitalization.

As such, further research is suggested on hospitalized frail elderly patients to explore the ND and address morbidities that prompt hospitalization, with a view to substantiating them as risk factors and including them in the NANDA-I nursing diagnosis of risk for frail elderly syndrome.

A limitation of this study was that the methodology used did not establish a cause and effect relationship be- 
tween the variables analyzed. By contrast, this limitation strengthens the assessment of risk factors for the ND risk for frail elderly syndrome among hospitalized elderly.

\section{DEFERENCES}

1. Fried LP, Tangen CM, Walston J, Newman AB, Hirsch C, Cottdiener J, et al. Frailty in older adults: evidence for a phenotype. J Gerontol A Biol Sci Med Sci. 2001[cited 2017 Aug 21];56(3):M146-56. Available from: https://www.ncbi. nlm.nih.gov/pubmed/11253156.

2. Borges CL, Silva MJ, Clares JWB, Bessa MEP, Freitas MC. Frailty assessment of institutionalized elderly. Acta Paul Enferm. 2013;26(4):318-22. doi: http://dx.doi. org/10.1590/50103-21002013000400004.

3. Díaz-Toro F, Nazzal Nazal C, Verdejo H, Rossel V, Castro P, Larrea R, et al. Frailty in patients admitted to hospital with acute decompensated heart failure. Rev Med Chil. 2017;45(2):164-71. doi: http://dx.doi.org/10.4067/S003498872017000200003. Spanish

4. Maciel GMC, Silva HTA, Gonçalves RG, Ferreira JDL, Tietre SV, Menezes RMP. Frailty assessment and its association with sociodemographic and health characteristics in community elderly. Int Arch Med. 2017;10(134). doi: http://dx.doi. org/10.3823/2404.

5. Baldwin MR, Reid MC, Westlake AA, Rowe JW, Granieri EC, Wunsch H, et al. The feasibility of measuring frailty to predict disability and mortality in older medical intensive care unit survivors. J Crit Care. 2014;29(3):401-8. doi: http://dx.doi. org/10.1016/j.jcrc.2013.12.019.

6. Perez M, Lourenço RA. FIBRA-RJ Network: frailty and risk of hospitalization in the elderly in Rio de Janeiro, Brazil. Cad Saúde Pública. 2013;29(7):1381-91. doi: http://dx.doi.org/10.1590/S0102-311X2013000700012. Portuguese

7. Storti LB, Fabrício-Whebe SCC, Kusumota L, Rodrigues RAP, Marques S. Frailty of elderly patients admitted to the medical clinic of an emergency unit at a general tertiary hospital. Texto Contexto Enferm. 2013;22(2):452-9. doi: http://dx.doi. org/10.1590/S0104-07072013000200022.

8. Fabrício-Whebe SCC, Schiaveto FV, Vendrusculo TRP, Haas VJ, Dantas RAS, Rodrigues RAP. Cross-cultural adaptation and validity of the "Edmonton Frail Scale EFS" in a Brazilian elderly sample. Rev Latino-Am Enfermagem. 2009;17(6):10439. doi: http://dx.doi.org/10.1590/50104-11692009000600018.

9. Gale CR, Cooper C, Sayer AA. Prevalence of frailty and disability: findings from the English Longitudinal Study of Ageing. Age Ageing. 2015;44(1):162-5 doi: https://doi.org/10.1093/ageing/afu148.
10. Gesualdo GD, Zazzetta MS, Say KG, Orlandi FS. Factors associated with the frailty of elderly people with chronic kidney disease on hemodialysis. Cienc Saúde Coletiva. 2016;21(11):3493-8. doi: http://dx.doi.org/10.1590/1413812320152111.18222015. Portuguese

11. Carneiro JA, Ramos GCF, Barbosa ATF, Mendonça JMG, Costa FM, Caldeira AP. Prevalence and factors associated with frailty in non-institutionalized older adults. Rev Bras Enferm. 2016;69(3):435-42. doi: http://dx.doi. org/10.1590/0034-7167.2016690304i.

12. Herdman TH, Kamitsuru S. Diagnósticos de enfermagem da NANDA: definições e classificaç̧̃os 2015-2017. Porto Alegre: Artmed; 2015.

13. Mello AC, Engstrom EM, Alves LC. Health-related and socio-demographic factors associated with frailty in the elderly: a systematic literature review. Cad Saúde Pública. 2014;30(6):1143-68. doi: http://dx.doi.org/10.1590/0102-311X00148213.

14. Melo NCV, Ferreira MAM, Teixeira KMD. Condiçōes de vida dos idosos no Brasil: uma análise a partir da renda e nível de escolaridade. Oikos: Rev Bras Econ Doméstica. 2014[cited 2017 Aug 25];25(1):4-19. Available from: http:// www.seer.ufv.br/seer/oikos/index.php/httpwwwseerufvbrseeroikos/article/ view/154.

15. Linck CL, Crossetti, MGO. Fragility in the elderly: what has being produced by nursing. Rev Gaúcha Enferm. 2011;32(2):385-93. doi: http://dx.doi. org/10.1590/S1983-14472011000200024. Portuguese

16. Garćáa-Esquinas E, Rodríguez-Artalejo F. Environmental pollutants, limitations in physical functioning, and frailty in older adults. Curr Environ Health Rep. 2017;4(1):12-20. doi: http://dx.doi.org/10.1007/s40572-017-0128-1.

17. Silva VA, D'Elboux MJ. Factors associated with urinary incontinence in elderly individuals who meet frailty criteria. Texto Contexto Enferm. 2012;21(2):33847. doi: http://dx.doi.org/10.1590/50104-07072012000200011.

18. Borrego CCH, Lopes HCB, Soares MR, Barros VD, Frangella VS. Causes of malnutrinion, sarcopenia and frailty in elderly. Rev Assoc Bras Nutr. 2012[cited 2017 Aug 28];4(5):54-8. Available from: https://www.rasbran.com.br/rasbran/article/view/128/106. Portuguese

19. Yanagita I, Fujihara Y, Eda T, Tajima M, Yonemura K, Kawajiri T, et al. Low glycated hemoglobin level is associated with severity of frailty in Japanese elderly diabetes patients. J Diabetes Investig. 2017 May 27. doi: http://dx.doi.org/10.1111/ jdi.12698. [Epub ahead of print].

20. Nguyen TN, Morel-Kopp MC, Pepperell D, Cumming RG, Hilmer SN, Ward CM. The impact of frailty on coagulation and responses to warfarin in acute older hospitalised patients with atrial fibrillation: a pilot study. Aging Clin Exp Res. 2017;29(6):1129-38. doi: http://dx.doi.org/10.1007/s40520-017-0733-8.
- Autor correspondente:

Letice Dalla Lana

E-mail: leticedl@hotmail.com
Received: 10.19.2017

Approved: 12.26.2017 